\title{
To vote or not to vote? The political orientations of Millennials in a comparative perspective
}

\author{
MAŁGORZATA ZACHARA*
}

Faculty of International and Political Studies, Jagiellonian University, Krakow, Poland

Received: May 5, 2020 • Revised manuscript received: June 30, 2020 • Accepted: July 7, 2020

Published online: August 11, 2020

(c) 2020 The Author(s)

\begin{abstract}
This article concentrates on the transformative potential of the Millennial generation within the framework of the political landscapes of the United States, several European countries and Russia. Generational experiences frame the context for the comparative examination of the democratic order and the perspectives for democratic transition. In Western countries, the group is a potentially powerful political force, yet its members do not pursue traditional forms of civic engagement - they are sceptical about institutional forms of participation and have little trust in public authority. Embedded in a youth-marginalization discourse, the public identities of the Millennials are seen rather as a manifestation of the failures of democratic representation, rather than as forms of agency seeking new ways of political expression. The orientations of this distinct group also present a puzzle when the future of authoritarian regimes is discussed: Millennials' openness to political change is often questioned, despite the prominent role they play in the rise of the opposition forces that gained influence during Vladimir Putin's third term. Nevertheless, in both contexts, the ongoing generational shift has become an increasingly important area for social-scientific investigation and it is being directly related to broader arguments about the nature of political change.
\end{abstract}

\section{KEYWORDS}

millennials, Russia, United States, Europe, political behaviour

JEL CODES

P5, I3, E7

*Corresponding author: E-mail: malgorzata.zachara@uj.edu.pl 


\section{INTRODUCTION}

Born after 1980, Millennials constitute the first generation to come of age in the new millennium, and in the United States they are the most populous generation ever (24 per cent of the U.S. population, U.S. Census Bureau 2013). They are also probably the most educated generation in history (Fry - Parker 2012). An orientation towards political or civic activities is seen as one of the distinctive subjectivities embedded in the portrait of the social generation of Millennials. From the sociological analyses there arises an image of a new generation that lags behind older generations in terms of its interest in government and politics (Grasso 2016; Harvard Kennedy School 2017; Shames 2017). The commonalities between the worldviews, values and behaviours of the Millennial generation in different countries have been captured in the perspectives of economic tendencies, future work markets and marketing trends (Deloitte 2018; Schewe et al. 2013), but there is a lack of systematic knowledge on how the political behaviours of this group are similar or vary across countries. Such a comparative perspective is needed, as the main trends of the Millennial generation are transnational in nature and reach. Using data from several different countries (USA, Western and Eastern European countries and Russia) this article argues that factors of social change and new risks may be common for a wide range of societies, but their interpretations and the reactions to them vary according to the particular conditions facing generations of young people.

The major analytical concern of the article is the condition of democracy in the Western societies, seen also in the context of the prospect of the democratic transformation in autocratic Russia. The entrance of the Millennials into the Western political realities has occurred at a time when the instability rooted in the crisis of the liberal democratic model is increasingly struggling to retain traction against a pushback from nationalism and different kinds of radicalism. So on the first conceptual level, the article intends to present the evolution of the Millennials' political behaviours in the context of the current moment of evolution of the Western democratic model. The second level of analysis comes into play at this point: Millennials are considered to be the first generation to fully embrace a global perspective on the world. Their status as 'the first globals' has been altered by changing national conditions, the acceleration of globalisation processes and technological innovations. This assumption underlies the cross-national comparative perspective of the article, as even if we assume some degree of affinity of the Western societies towards the values that define democracy, there is certainly a high degree of fragmentation in the ways in which they understand modernity and experience globalisation. Given the scale of complexity of the social organisms in the discussed states and the variety of areas in which attitudes towards politics can be traced, the direct comparison of the national cohorts of Millennials goes beyond the scope of this article. It aims rather to identify specific conditions that might potentially play a role in the further development of the democratic model in the United States, European countries and Russia, and analyse those in the context of the generational features of the Millennial generation. Due to the broad and diverse geographical and cultural scope of the analysis, the political orientation of Millennials is analysed trough the interpretation of everyday social practices that seem important in the context of the national political culture. Rather than providing conclusive evidence the text is oriented towards testing the potential of the subject and suggesting directions for future research. 


\section{RESEARCH BACKGROUND}

The article aims to indicate different aspects of political transformation, the rise of nationalism or the decline of liberal ideals, as conditions that create distinctive opportunities and risks that young people must navigate. It uses the sociological perspective of generation to trace changes in orientation towards politics and social activism. Age is seen as a variable enabling the tracing of changes in views and behaviours, because of the generation's size, already recognized distinctive features of the dominant generation and the potential of its members to introduce new norms and operational patterns to the sphere of political activity. The tradition of reflecting on the influence of age groupings for processes of social change can be traced back to the Greek philosophers, but it is the essay of Karl Manheim 'The Problem of Generations' published in 1923 that is considered to be the seminal theoretical treatment of generations from a sociological perspective. Members of a generation share a common location in the social and historical process which is connected to 'certain definite modes of behaviour, feeling and thought' (Manheim 1928/1952: 291). It has been widely recognised that generations are more socially than biologically constructed and gain social significance by virtue of constituting themselves as cultural identities (Bourdieu 1993; Edmunds - Turner 2002: 7).

Attention is paid to the psychological dimension of the concept, indicating shared identities and dispositions across a generation. This is especially valid with regard to the common, evidence based assertion that the Millennial generation is more narcissistic than previous generations, so the individual, psychological condition of the youth may, to a greater extent than previously, transform the social environment (Campbell et al. 2005; Twenge 2006; Twenge Campbell 2009).

Millennials are perhaps the most studied generation to date, but it should be noted that most of the studies regarding this age cohort have been conducted in the United States of America (Daugherty - Copen 2016; Fry-Parker 2012; Pew Research Center 2010). Western and global perspectives on Millennials, then, have been constructed to a great extent on the basis of the studies concerning American youth. This generation, comprising the 74 million-plus young people born from 1982 to 2002 is now the nation's largest - its scale and distinctive profile brings transformational potential comparable to that of the Baby Boomers (U.S. Census Bureau 2013).

In Europe, although the Millennial phenomenon has been widely recognised, the shift would not be so radical because of the smaller relative size of the generation compared to other generations in most of the countries. Some of the features of the contemporary environment are also common to young Europeans, Canadians, Australians and Asians, which provided grounds for the label of 'global generation'.

The key factors of Millennial influence in the political sphere can be categorised into three major generational narratives.

\section{a) Technology/Media Use}

All of the authors explaining the generational profile of Millennials stress the fact that the use of digital technology impacts their lives to a greater extent than the generations preceding them. According to Gumpert and Cathcart (1985), the worldviews and relationships of every generation are influenced by the media ecology of their youth years. In the case of Millennials, the cyber media technological coordinate stands for a distinctive generational feature, as they are 
immersed in an info-reality that shapes their opinion and directs their actions. The result of extended technology and media use for the political orientations of Millennials, as of previous generations, is not conclusive. A Media Insight Project, 'How Millennials Get News: Inside the Habits of America's First Digital Generation', found that 'becoming an informed citizen' is the most important reason Millennials have for using news and information (Media Insight Project 2015: 8). The different view was reached by a nine-country survey by Curran et al. (2014), according to which 37 per cent of people from the age group 18-34 years 'do not seek information, on a regular basis, from any news medium, compared with only 13 per cent of those aged over 54-years-old' (2014). Millennials have led older generations in their adoption and use of technology, but this is not representative of the scale of their political and public involvement. Social media and technology are used as mediums for political engagement, expressing views or sharing opinions rather than for entering formal politics. Some scholars see this as the result of a diminishing interest in social issues and even of a more general deterioration in civic culture (Banaji - Buckingham 2013). Others claim that young people still feel socially engaged by participating in online activism and creating a vital forum for political discourse (Christensen 2011). There is, however, no clear cause-effect linkage between involvement and political gains, which can contribute to a sense of powerlessness and political disconnection.

b) Economic and Social Instability

The list of the formative experiences of the Millennials includes not only global recession but also growing exposure to diversity, emancipation movements and an increasing sense of instability. The image of the moral order of society has been seriously tarnished by the unprecedented corporate scandals (Enron, Arthur Andersen, TYCO), terrorist attacks (9/11, Beslan, Madrid, London, Berlin, the Paris attacks, the Charlie Hebdo attack), series of gun violence in public spaces (the Columbine school massacre and other school shootings, the Anders Breivik massacre in Norway). A stagnant economy has shaped the way Millennials perceive the world, participate in political life and the manner in which their generational consciousness is formed.

c) Intrinsic Values

The distinctive generational features of Millennials have been categorised into two sets. One has been labelled 'Generation $\mathrm{Me}^{\mathrm{e}}$ and profiles the representatives of this group as narcissistic, impulsive, and sheltered. They have been also described as self-centred, overly ambitious people who believe they are special. The list of the most highly-prized values includes social position, image, and fame (Gordinier 2009). This assertion is mainly based on psychological research led by Jean Twenge, who has been studying the shift in the generational outlook for more than 15 years (Twenge 2006; Twenge - Campbell 2009). The results of cross-temporal meta-analyses of narcissism and empathy levels among college students over the past three decades indicate decreases in empathic concern (i.e., sympathy for the misfortunes of others) along with increases in narcissism (Konrath et al. 2011; Twenge et al. 2008). The latter is associated with the dynamics of individualistic culture, changing family and educational models, and the spread of a high-involvement parenting style.

According to the contrasting portrait of young Americans, 'Generation We' presents itself as public-spirited, idealistic, and collaborative (Arnett 2013; Greenberg - Weber 2008; Williams et al. 2010). Research demonstrates that representatives of this generation are more community 
oriented, caring, activist, civically involved than previous generations. The intention of bringing changes to the world seems to be a strong factor in the generational profile. Almost two-thirds of Millennial employees said they wanted their employer to contribute to social or ethical causes they felt were important. Only half of the Boomers and older Gen Xers surveyed felt the same way (LifeCourse Associates 2012).

\section{MILLENNIALS IN EUROPEAN POLITICS}

The variety of Millennial preferences and behaviours fits well in the diverse and complex landscape of European politics. The primary focus of analysis for the European Union is formed by growing signs of a split between the Central European and Eastern European member states. Divergent interests, political styles and non-compliance with the basic principles underpinning the EU undermine not only the prospect of further integration but the overall position of Europe on the global scene. How do Millennials fit into this picture? In the liberal perspective, youth is seen as a force of modernity and innovation, which stands in stark contrast to the fact that in Europe Millennials have taken the lead in far-right and popular nationalist movements. The farright populist sweep into the German parliament for the first time since 1945 is a prominent example, though these kinds of parties have also performed particularly well among Millennial voters in Sweden, Poland, Slovakia, Hungary and France (Stockemer 2018). Heading in a different direction than might have been expected, and in many cases contradictory directions, Millennials have demonstrated an ability to act independently and express their will. Throughout 2017, signs of a youthocracy could be seen on the European electoral scene, as young voters played an important role in three major national elections. In France, Emmanuel Macron become France's youngest-ever president. In Germany, Angela Merkel gained the substantial acceptance of young voters, while the youth wing of the Christian Democrats (CDU) and Christian Social Union (CSU) of Merkel's conservative bloc grew to be Europe's biggest organization for political adepts. In Austria, 33 year old Chancellor Sebastian Kurz, also elected in 2017, for two years represented the Millennials on the national scene. On the other hand, public debate on Britain's presence in the European Union exposed the differences in worldviews between Millennials and Baby Boomers and ended as a failure for the new generation. In online polls conducted by YouGov after the Brexit referendum, it transpired that 71 per cent of the population aged 18-24 voted to keep the United Kingdom in the European Union, a figure that decreases rapidly with rising age. By comparison, only 36 per cent of the population aged over 65 voted for the United Kingdom to stay (YouGov 2016). The generational divide revealed by this process marks European public debate over many other competing spheres of interests.

Demographic change has long been a major political theme in several European countries. In the current EU member countries the population cohort between the ages of 15 and 64 is expected to decline from 67 per cent of the total population to 56 per cent by 2060 . The population group aged 60 and older is expected to grow from 18 per cent to 30 per cent in the same period (Eurostat 2017). In the face of such challenges, governments focus on reconstructing pension systems, raising the retirement age and changing the system of public finances, introducing social measures to adjust to the situation in which fewer people will have to create the resources. This higher proportion of the elderly in European societies has marginalised young people. Additional support for the 'silver group'-concentrated policies created the fact that the older 
generation is the one which votes reliably. The MYPLACE (Memory, Youth, Political Legacy and Civic Engagement) research project conducted in 14 countries across Europe in order to provide a view of Millennials' engagement, revealed distrust and an overriding feeling that politicians are not interested in young people 'like them' (MYPLACE 2015).

International pressures, especially those resulting from the severe migrant crisis that affected Europe in recent years, are another long term factor that keeps governments away from focusing on the agency of younger people. The combination of security threats shifted public focus to the idea of safety, which is increasingly perceived as a major value at a time when powerful processes deeply impacting the social structure seem to be beyond states' influence and control. Against this background, European youth were especially exposed to radical agendas of the nationalistic groups. Standing up for national sovereignty and identity in times of social change and perceived crisis seemed to be a reasonable choice. The trend expanded to other areas of European politics and may be tracked to the centre of a conservative cultural revolution in Poland and Hungary. While the far-right parties responsible for the shift in politics have moderate support between young Poles and young Hungarians, it seems that the ideas they stand for fit well with the Millennial vision of reality. There is no systematic data demonstrating the scale of youth involvement, but governmental and market research sources indicate that about 20 per cent of the nation's Millennials support the ruling forces in Poland. A Wall Street Journal analysis of polling data showed that in Poland's 2015 elections the Law and Order (PiS) party received 25.8 per cent of the votes from Poles between the ages of 18 and 29 (Centrum Badania Opinii Publicznej 2015). In this picture, however, it is not youth participation but rather inaction that seems to be the crucial factor. The youth are considered to be likely to question existing political regimes, as youthfulness bears in its nature radical elements and revolutionary spirit. But this time in Central Europe the morale-raising spectacle of the street demonstrations did not appeal to young people. A conventional explanation is the fact that young people do not recognise the danger represented by these governments, because they have never lived under authoritarian or totalitarian regimes.

The economic framework strongly influences the perception of reality and cultural identity of the young generation. Although Millennials have the widest ever array of technological instrumentation at their disposal, their self-perception is concentrated on disadvantages. Unlike the previous generations, raised in a 'hard work' and 'harsh world' ethos, Millennials seem to be more moderate in their ambitions and not unequivocally optimistic about their life possibilities. European Millennials have suffered disproportionately from their countries' recent economic troubles. In 2013 youth unemployment in Greece stood at 60 per cent, while in Spain, the number was 57 per cent and in Ireland more than 30 per cent (Dietrich - Möller 2015). Little wonder that Foreign Policy's 2015 diagnosis was that 'Europe's kids are moody and depressed' (Stokes 2015).

Surprisingly, this attitude is common also in societies that have enjoyed more recent economic success. Poland, for example, is experiencing a golden age of growing prosperity and the internationalization of a young generation that still has prospects of reaching the economic standards established by their parents. Nonetheless, their perspective is far from optimistic. Even with an average GDP growth of 4.2 per cent since the country joined the EU, young Poles are feeling left out of the country's success. The socio-economic framework has been changing dynamically throughout all of their lives. Most of the norms and guidelines of life that Millennials observed while growing up, and instinctively inherited from their parents' experience, 
are becoming out of date. They lack cultural manuals that could be useful in helping them navigate their lives through the post-work era and at a time of social change. In the case of young Poles and other Eastern Europeans, work stability and security are highly valued features of the system, underpinning the individual's definition of success. These expectations of young people and their families stand in contradiction to the market realities of a high youth unemployment rate, and the dominance of the freelance working model without job security. Young people from developed economies like Italy, France or Spain face this problem with increased intensity, but even in Germany, privileged in terms of the employment market, there are signs of cultural change forged by transformed economic realities.

In Western Europe, young people may be more aware of the change in the social contract demographic asymmetry and fragile market realities force them to concentrate on individual strategies. In Central-East Europe, such a discourse has not yet gained so much exposure. In addition, the public has grown tired of the highly competitive individualistic life-styles that have dominated since the socio-economic transformation. All this has created a favourable background for conservative narratives exploring themes of national and group identities. The farright part of the political spectrum absorbs this communitarian-minded younger group, putting them at the forefront of its conservative cultural revolution. The other part of the Millennial generation stresses self-reliance and individual strategies of success within a globalised world. Being the first ERASMUS generation fully experiencing the free movement of people in Europe and broadly able to speak English, they are internationally oriented. Signs of attachment to the fatherland have private rather than public, national sources.

\section{MILLENNIALS IN RUSSIAN POLITICS}

The orientations of the younger generation of voters in Russia are especially interesting in the context of the chances for regime transformation, as well as the ability of the current leadership to manage the uncertainty related to coronavirus epidemics, evoking a different kind of social crisis. Millennials in Russia are often described as 'the Putin generation'. Being a part of a not fully modernised society, they gain access to the platforms and items that characterise global Millennials in the era of Vladimir Putin's long presidency. Data from an opinion poll conducted by the independent Levada Center demonstrates that Russians aged 18-24 put more trust in the country's main political figures and institutions than older generation (Levada 2017). In 2017 Putin's approval rating among 18-24 year olds was 91 per cent (Rakhlei 2017). The presidential elections in 2018 gathered the first cohort of voters to have known no other leader than Vladimir Putin, as 18-34 year olds constituted 30 per cent of eligible voters. Young people have long been a target of intensive political indoctrination; they are subjected to 'patriotic education' in schools and exposed to the President Putin's cult of personality. In addition, in 2015 the military's youth organization, the Yunarmiya Patriotic Movement, was created to encourage support from Russia's next generation. The organisation has grown substantially to more than 140,000 members, aged between 11 and 18 (Monaghan 2017: 158). President Putin's approval ratings remain at a high level among the young and pro-Kremlin sentiments are visible in the Russia's socio-political environment. In 2019, 69 percent of Russians under the age of 25 supported the president (Levada 2019). But the picture of the whole generation is inconsistent. In 2017, Millennials also stood at the forefront of the opposition, presenting a major force in a series of 
rallies in defiance of the government. The scale of the involvement of the youth in the demonstrations caught commentators by surprise. They have been mobilised by Alexei Navalny, who became Russia's best-known blogger and activist. He has built an anti-corruption campaign through his blog and YouTube and used these channels to organise several mass rallies across Russia, gaining the status of a major opposition figure. In early 2018, after he led a series of mass riots, he was eventually convicted of embezzlement and sentenced to five years in prison. Further to that, Russia's Central Election Commission unanimously rejected Navalny's bid to run against President Putin in the presidential race.

This process, which was viewed by many to be a sign of an awakening of the Russian youth, has some of the typical features of Millennial behavioural patterns. The momentum grew largely because of a long-term campaign based on social media and YouTube, which mixed issues that Millennials are concerned about with pop-cultural trends. Accustomed to the real-time communication and authenticity found in Navalny's work - a blog on Russia's Live Journal and a network of Russian citizens exposing the corruption of state-run companies - young people came to see these activities as a valuable source of information. The release of a documentary about Prime Minister Dmitry Medvedev's involvement in corruption became a starting point for the protests. This documentary accuses Medvedev of concealing his ownership of 'palaces, yachts and wineries'. The movie garnered more than 15 million views on YouTube - ten times more than any other investigative report by the Anti-corruption Foundation, more than any content produced by non-state-controlled media.

In 2017, young Russians took to the streets; demonstrations brought together a large number of college students and recent graduates, with the median age of protesters declining significantly in the comparison to 2011-2012. This may be associated with the fact that the importance of the problem grew over time. A study by the Russian Public Opinion Center, conducted in 2012, revealed that 48 per cent of Russians were worried by the spread of corruption (NEWSru.com 2012). In 2017, Transparency International's Corruption Perceptions Index ranked Russia 135th out of 180 countries (Transparency International 2017).

The involvement of young people in the protests has led to a response from the government, with parliament debating regulations banning young people from participating in demonstrations. A video titled 'Navalny 2018 Hitler 1945 We Can Repeat' is one of the vivid examples of the orchestrated government campaign to intimidate Russian students and young adults planning to participate in the opposition movement. Official government statements warned that minors are being instrumentalised by anti-government politicians such as Navalny.

So Russian youth is described, on the one hand, as Putin's 'puppets', and on the other hand as the main actors in protests against electoral fraud and corruption. They seem to be at a crossroads, as the 'Putin era' has for them meant a time of relative prosperity, marked by improved standards of education, freedom to travel, and the explosion of information technologies. The unemployment rate in Russia is steadily decreasing (reaching an all-time high of 14.1 per cent in 1999 and a record low of 4.7 per cent in March of 2019), consumer spending has been rising by more than 5 per cent annually; life expectancy, although exceptionally low compared with that in developed countries, has been rising; Internet penetration exceeds that of some countries in the European Union (OECD 2018). While foreign commentators call Putin's regime an ineffective, self-defeating, feudal dictatorship (Motyl 2016), the Russian political system seen from the inside, through the lens of the historical consciousness, seems to be producing a fairly successful social and economic organization. 
The identity of Millennials is rooted in the idea of the great Russia popularised by president Putin, but they want to remove irregularities and boundaries that stopped them from personal development and shadow the image of the society. Russia's Millennials are busy with their lives. They do not mind autocracy if the system does not interfere with their plans. Polls show that Russians between the ages of 17 and 34 appreciate above all peace in the family, prosperity, and health, but not personal freedom and independence (Rakhlei 2017). They exhibit hardly any rebellious political orientation. Most of them would prefer a correction of Russia's existing structures to radical change. They seem to be responsive to the Kremlin's critique of Western values and, while they may see the Western world in decline, at the same time they notice an opportunity to conquer it. That is why they are ready to rebel when the system blocks and disappoints them. The profile of Russian Millennials, therefore, differs from the one created in the West. A value-based conflict of generations never arose. The worldviews of Russian Millennials may well fit into the framework of a new kind of nationalism, one that draws on narratives of historical tradition, religion and a civilizational stand-off with the West. Appeals to 'conservative values' are explicitly presented as an alternative to Western liberalism, particularly when it comes to the rights of the LGBTQ community, religious minorities, women and other historically disadvantaged groups. While in Western Europe and the United States hipster culture revealed post-materialistic orientations among young people, in Russia personal success is defined mainly in material terms. Young Russians, like their peers in the post-Soviet area, greatly value material wellbeing and status. Military spending and foreign adventures are eating up a large part of the federal budget, even prompting a small reduction in spending on armaments in the coming year. People are becoming increasingly fatigued by Russia's interventions in Ukraine and Syria. They are also infuriated by the luxurious lifestyles of Russian officials and their families. Furthermore, declining energy prices have been negatively affecting the living standards of ordinary citizens, and the international sanctions imposed in the aftermath of the annexation of Crimea add to the general picture of uncertainty. The form of kleptocracy run by the Russians to enrich the political inner circle is being gradually contested (Dawisha 2014). But rather than a call for reform, there is an appeal to correct the existing course. In the Russian reality, the vast division between elites and the general public does not bring popular frustration (Inozemtsev 2009). The dominant status of the politically powerful class is not questioned, for it fits into the general picture of national pride. Due to cultural and historical backgrounds, elitism and corruption are more accepted as part and parcel of the system.

While youth protest in itself is important, as it shows that there is clearly some resentment building up among the younger generation, does this necessarily signify a generational revolt in the making? Julia Hemmet, in her book about Russian youth, suggests, that the Russian experience is best understood not in isolation - as most mainstream accounts prefer - but as part of the broad renegotiation of the contract between state, civil society, and individual citizens' (Hemment 2015: 10). A combination of state-produced ideologies and the search for individual identity made Russian Millennials responsive to anti-modernization and antiWestern narratives. They see Western ideologies, ways of life and societal arrangements as declining, and the copying of them as a sign of civilizational inferiority. This is combined with imperial mythologies and a growing market demand for patriotic ideologies. Such a view can be influenced, however, by the economic situation, as economic freedom is one of the top declared priorities of young people in Russia, as they measure themselves against their Western peers. 
The need for political change could be strengthened by a generational change that produced identities, life patterns and criteria for subjective well-being different from the older generations of Russians.

\section{MILLENNIALS IN AMERICAN POLITICS}

One in three adults in America belongs to the Millennial generation and 50 percent of the workforce was forecasted to be composed of its members in 2020 (U.S. Census Bureau 2013). Any group of that size has the potential to transform health care, education, the environment and other public policies, as long as it is coherent in its vision and goal-oriented. Studies of the Millennials in the United States have brought to the fore a wide range of issues, and they have made their mark in workplace relations, consumer strategies, educational policies and national identities. The political and institutional landscape observed through the lens of the needs and characteristics of the new generation provides some knowledge about the possible directions of the on-going social change. The major criteria through which generational transition will be observed is the decline in economic and international pre-eminence of the United States, reflected in growing political polarisation and unfavourable social conditions. This situation has not produced any kind of intensified interest in politics, or a revival of political participation. The 2016 presidential elections may be considered representative for the Millennials, as all of them reached voting age. Although the election campaign revealed some information about youth orientations and ways of thinking, their involvement did not change the course of events but their passivity may have. The political affinity of the Millennials in the election of 2016 was clear - they demonstrated their support for the Democratic candidate Hilary Clinton who received 55 per cent of vote in the 18-29 year group, over Donald Trump's 37 per cent (Omri 2016). This electoral result did not, however, live up to some people's expectations, since in the 2012 election Barack Obama won 60 per cent of the vote among those under 30 (CIRCLE 2012). Howe and Strauss (2000: 3), authors of 'Millennials Rising: The Next Great Generation', claim that 'for decades, Americans have been waiting for a youth generation that would quit talking and start doing.' However, the expectations invested in the electoral performance of the Millennials failed to materialise. There are estimates that if the additional 5 per cent of young voters that participated in the previous election had gone to the polls the overall result might have been different (Mosendz 2016).

Involvement in institutional structures, however, seems to better indicate the changing orientations of the young voters than election turnout alone. Traditionally in the United States, young people have the lowest turnout, though as the individual ages, turnout increases to a peak at the age of 50 (Klecka 1971: 369). This long-evident pattern has not changed, even though in the 21 st century the Internet and mobile communication channels are widely used as an opportunity to mobilise and engage young voters.

The disengagement of youth has been seen since the beginning of the 21 st century as an aspect of a general trend of social withdrawal from the public sphere to the private one. The American National Election Study revealed that the number of Americans 'very much interested' in political campaigns has dropped by nearly 40 per cent since the 1960s (Green - Shea 2007: 22). Nielson Media Research data indicate that the number of Americans watching the presidential TV debates has shrunk by nearly 50 per cent since 1980 (Shea 2004). This 
interpretation, although fitted well to the period of relative stability and prosperity, proves to be wrong in moments of turbulence. Young voter turnout data reflects this. In 1972, the first election in which 18-year-olds had the right to participate, 55 per cent voted (CIRCLE 2004). In the election of 2000 the percentage shrank to 29 (CIRCLE 2004). After that however, this long trend was reversed, and nearly five million more young adults voted in 2004 than had done so four years earlier. Voter turnout increased sharply, reaching its highest level since the 1968 presidential election (Cohen et al. 2016: 7-10). But this was only a start. Young voters' interests and involvement reached their peak in the 2008 election, when Barack Obama received his strongest support from the 18-29 year-old voting bloc. Young people, minorities and women made up the coalition that resulted in Obama's electoral successes in 2008 and 2012.

It is hard to claim that young Americans are a 'switched off generation on the basis of this data. Quite the opposite: they are able to generate support and become actively involved in the political process. But they do it on their own terms, when the environment in which this process takes place seems adaptable and when they find links between the political landscape and their own.

The paradox lies in the fact that there have been many voices predicting the natural decline of the Republican Party caused by shifting demographics and the United States' changing ethnic composition. The candidates of the Grand Old Party were all seen as old white men and its policies as only appealing to a shrinking proportion of white Americans. This proved to be enough, when young voters chose to be uninvolved. Their scepticism toward 'old school politics' is based on the same grounds as that of their parents and grandparents when they were young themselves. The image of Washington D.C. as a depraved, broken place is still strong, but in the past young people always found incentives to become a part of political realities and try to change them. Millennials seem reluctant to take this path. The extensive study of the political behaviours of US Millennials by Shauna Shame (2017) reveals that those most suitable for playing leading roles in politics - graduate students at Harvard and Suffolk Law Schools and Harvard's Kennedy School of Government - find electoral politics unrewarding. Their decisionmaking process is based on rational calculations, and the costs (a lack of privacy, constant fundraising requirements, hyper partisanship, or other additional costs for women like sexism or double standards) prevail over the benefits (solving important problems or making positive change). The Harvard Institute of Politics' data indicates that between 2000 and 2017 trust towards the federal government decreased among American youth by 10 points, dropping to historically low levels (Harvard Kennedy School 2017). In 2014, the majority of Millennials (52 per cent) stated that they would choose to recall all members of Congress, were it possible. In 2017 the proportion of young people interested in public service dropped from 31 to 25 per cent. Nine per cent of 18 to 29 -year-olds expressed interest in pursuing some kind of public office between now and when they turn 50 (Harvard Kennedy School 2017).

The young generation may be rejecting old political allegiances and trying to use other frameworks to collectively build a progressive, fair society (Arnett 2013; Bucic et al. 2012). A paradigm shift in this respect would be appreciated, but evidence for its emergence is weak so far. The worldview of young Americans is strongly influenced by political and economic turmoil: the combination of terrorism, the human costs of the wars fought in Iraq and Afghanistan, lost manufacturing jobs, unparallelled foreclosures, a shocking drop in property values, and many other factors. Established frameworks of inequality and limited space in the systems of power have deprived part of the Millennial generation of economic opportunities. 
It should be emphasised that young Americans are highly divided in their experience, a fact which substantially influences their worldviews. Young Black and Latino people are disproportionately exposed to social crises. Poverty, HIV/aids, childhood obesity, incarceration, and unemployment mark their lives and political orientations more strongly than their white peers (Dawson 1994; Walton - Smith 2014).

American Millennials seek stability in a time that undermines traditional cause-effect patterns of social life and individual success. What was a fundamental social belief - that education is the way to success in the labour market - has proven to be more complicated in a globalised economy. Higher education is an indispensable attribute in a path to a prestigious career, but the competition for entry into the shrinking pool of middle-income jobs is steadily growing. In effect, young people who have invested their dreams and money in diplomas tend not to get their prize after graduation. In fact, quite the opposite has now happened - student debt has long been a lifetime burden. The economic worldviews of Millennials have been shaped by two major factors: the Great Recession, which hit them harder than it affected older generations, and the explosive growth in student debt (Buckley et al. 2015).

Relative depravation as a sign of growing income inequality combined with well-established frameworks of a meritocratic society model deepened the state of political discontent expressed by withdrawal from the public sphere. Members of the leading US generation have become more individualistic and self-oriented. In consequence of the breakdown of trust between the elites and the people, they have abandoned traditional forms of political participation, which adds another factor to the list of concerns about the status of democratic representation in the American system.

\section{CONCLUSION}

Although the socio-cultural realities of the countries in which Millennials' attitudes towards politics have been analysed here differ profoundly in some aspects, the data suggest that the Millennial generation is sceptical towards the established rules of the political game. The reluctance of its members to take on political roles may further erode democratic norms in the Western world and negatively influence the prospect of democratic transitions elsewhere. A comparison of the political attitudes of the representatives of the Millennial generation indicates the significance of their national and regional contexts, weakening the notion of the 'first globals'. Millennials are commonly aware of global problems, such as the environment or sustainable development, but this fact does not translate into the more globalised orientations of national governance bodies. The dominant generation does not seem to be influential in translating their orientations into political strategies, because they generally reject the rules by which politics is made. This is the common feature joining Millennials in the autocratic Russia, new democracies in Eastern Europe and more established European and American democracies. The political profile of the Russian Millennials does not provide basis for the possibility of the internal transformation of the regime towards democratization. On the one hand, the Kremlin's attempts at sowing confusion and eroding trust in globalised narratives and institutions have long proved to be effective. On the other hand, the attractiveness of the Western democratic model for the new, powerful generation of the Russians is not the only option that is on the table. 
The political reluctance of the Millennial generation in the Central-Eastern Europe is also interesting in the context of the attractiveness of the Western democratic project. The example of Poland, that has been viewed as a model case of peaceful transition from a totalitarian system, is symptomatic in this respect. The fact that the model is questioned in the most successful of the Europe's 'new democracies' undermines the organising principle of the dominant vision of the World Order. Political behaviours of the Millennial generation in the United States and Western Europe add to the general picture of the democratic ideal in crisis. The data presented above illustrate an increasing trend that should be further analysed in order to document the dynamics of the transformation of political systems. These preliminary results are important in mapping the direction and pace of the change, as Millennials will be occupying prominent places in the social structures of their countries in the years to come, and their orientations will be decisive in the further erosion or revival of the democratic institutions.

\section{REFERENCES}

Arnett, J. (2013): The Evidence for Generation We and Against Generation Me. Emerging Adulthood 1(1): 5-10.

Banaji, S. - Buckingham, D. (2013): The Civic Web: Young People, the Internet, and Civic Participation. Cambridge: MA-MIT Press.

Bourdieu, P. (1993): Sociology in Question. London: Sage.

Bucic, T. - Harris, J. - Arli, D. (2012): Ethical Consumers among the Millennials: A Cross-National Study. Journal of Business Ethics 110: 113-131.

Buckley, P. - Viechnicki, P. - Barua, A. (2015): A New Understanding of Millennials: Generational Differences Reexamined. Issues by the Numbers. http://dupress.deloitte.com/dup-us-en/economy/issuesby-the-numbers/understanding-millennials-generational-differences.html, accessed 13/07/2020.

Campbell, W. K. - Bush, C. P. - Brunell, A. B. - Shelton, J. (2005): Understanding the Social Costs of Narcissism: The Case of Tragedy of the Commons. Personality and Social Psychology Bulletin 31: 13581368.

Centrum Badania Opinii Publicznej (2015): Przepływy Elektoratów w Wyborach Parlamentarnych 2011 i 2015. Komunikat z Badań nr 166/2015. http://www.cbos.pl/SPISKOM.POL/2015/K_166_15.PDF, accessed 13/07/2020.

Christensen, H. S. (2011): Political Activities on the Internet: Slacktivism or Political Participation by Other Means? First Monday. http://firstmonday.org/article/view/3336/2767, accessed 13/07/2020.

CIRCLE (2004): The Youth Voter 2004: With a Historical Look at Youth Voting Patterns 1972-2004. CIRCLE Working Paper 35.

CIRCLE (2012): Diverse Electorate: A Deeper Look into the Millennial Vote. https:/civicyouth.org/ wpcontent/uploads/2012/11/CIRCLE_2012Election_GenderRace_ForWeb1.pdf, accessed 13/07/2020.

Cohen, C. J. - Luttig, M. - Rogowski, J. C. (2016): Understanding the Millennial Vote in 2016. GenForward: A Survey of the Black Youth Project with the AP-NORC Center for Public Affairs Research. https://genforwardsurvey.com/assets/uploads/2016/12/Post-Election-Horse-Race-Report-__CLEAN. pdf, accessed 13/07/2020.

Curran, J. - Coen, S. - Soroka, S. - Aalberg, T. - Hayashi, K. - Hichy, Z. -Iyengar, S. - Jones, P. Mazzoleni, G. - Papathanassopoulos, S. - Rhee, J. W. - Rojas, H. - Rowe, D. - Tiffen, R. (2014): 
Reconsidering 'Virtuous Circle' and 'Media Malaise' Theories of the Media: An 11-Nation study. Journalism 15(7): 815-833.

Daugherty, J. - Copen, C. (2016): Trends in Attitudes about Marriage, Childbearing, and Sexual Behavior: United States, 2002, 2006-2010, and 2011-2013. National Health Statistics Reports 92.

Dawisha, K. (2014): Putin's Kleptocracy: Who Owns Russia? New York: Simon \& Schuster.

Dawson, M. C. (1994): Behind the Mule: Race and Class in African-American Politics. Princeton, NJ:

Princeton University Press.

Deloitte. (2018): Millennials Disappointed in Business, Unprepared for Industry 4.0. The 2018 Deloitte Millennial survey. https://www2.deloitte.com/content/dam/Deloitte/global/Documents/About-Deloitte/ gx-2018-millennial-survey-report.pdf, accessed 13/07/2020.

Dietrich, H. - Möller, J. (2015): Youth Unemployment in Europe - Business Cycle and Institutional Effects. International Economics and Economic Policy 13(1): 5-25.

Edmunds, J. - Turner, B. S. (2002): Generations, Culture, and Society. Philadelphia: Open University Press. Eurostat. (2017): Population Structure and Ageing. In: Europe in Figures - Eurostat Yearbook. http://ec. europa.eu/eurostat/statistics-explained/index.php/, accessed 13/07/2020.

Fry, R. - Parker, K. (2012): Record Shares of Young Adults Have Finished Both High School and College.

Pew Research Center. http://www.pewsocialtrends.org/2012/11/05/record-shares-of-young-adultshave-finished-both-high-school-and-college/, accessed 13/07/2020.

Gordinier, J. (2009): X Saves the World. New York, NY: Penguin.

Grasso, M. T. (2016): Generations, Political Participation and Social. Change in Western Europe. London, New York: Routledge.

Green, J. C. - Shea, D. M. (2007): Throwing a Better Party: Local Political Parties and the Youth Vote. In Green, J. C. - Shea, D. M. (eds.): Fountain of Youth. Strategies and Tactics for Mobilising America's Young Voters. Lanham: Rowman and Littlefield Publishers.

Greenberg, E. H. - Weber, K. (2008): Generation We: How Millennial Youth are Taking over America and Changing our World Forever. Emeryville, CA: Pachatusan.

Gumpert, G. - Cathcart, R. (1985): Media Grammars, Generations, and Media Gaps. Critical Studies in Mass Communication 2: 23-35.

Harvard Kennedy School. (2017): Survey of Young Americans' Attitudes Toward Politics and Public Service, 33rd Edition. Executive Summary. http://iop.harvard.edu/sites/default/files/content/docs/ 170424_Harvard\%20IOP\%20Poll_Spring\%20_Exec\%20Summary.pdf, accessed 13/07/2020.

Hemment, J. (2015): Youth Politics in Putin's Russia: Producing Patriots and Entrepreneurs. Bloomington: Indiana University Press.

Howe, N. - Strauss, W. (2000): Millennials Rising: The next Great Generation. New York: Vintage Books. Inozemtsev, V. (2009): The Nature and Prospects of the Putin Regime. Russian Social Science Review 50(1): $40-60$.

Klecka, W. (1971): Applying Political Generations to the Study of Political Behavior: A Cohort Analysis. Public Opinion Quarterly 35(3): 358-373.

Konrath, S. H. - O'Brien, E. H. - Hsing, C. (2011): Changes in Dispositional Empathy in American College Sudents Over Time: A Meta-Analysis. Personality and Social Psychology Review 15(2): 180-198.

Levada Center. (2017): О молодеЖи старой и новой. https://www.levada.ru/2017/05/23/o-molodezhistaroj-inovoj/, accessed 13/07/2020.

Levada Center. (2019): Approval of the Government. https://www.levada.ru/en/ratings/, accessed 28/07/ 2020. 
LifeCourse Associates (2012): Why Generations Matter: Ten Findings from LifeCourse Research on the Workforce. https://www.lifecourse.com/assets/files/Why\%20Generations\%20Matter\%20LifeCourse\% 20Associates\%20Feb\%202012.pdf, accessed 18/07/2020.

Manheim, K. 1928/1952. The Problem of Generations. In: Essays on the Sociology of Knowledge. Routledge and Kegan Paul, London.

Media Insight Project. (2015): How Millennials get News: Inside the Habits of America's First Digital Generation. Arlington, VA: American Press Institute.

Monaghan, A. (2017): Power in Modern Russia. Strategy and Mobilization. Manchester: Manchester University Press.

Motyl, A. J. (2016 March): Putin’s Russia as a Fascist Political System. Communist and Post-Communist Studies 49(1): 25-36.

Mosendz, P. (2016): What this Election Taught us about Millennial Voters? https://www.bloomberg.com/ news/articles/2016-11-09/what-this-election-taught-us-about-millennial-voters, accessed 13/07/2020.

MYPLACE (2015): Transnational Cluster Report. http://www.fp7-myplace.eu/documents/D7_2/D7.2\% 20Transnational\%20Report\%20Cluster\%206.pdf, accessed 13/07/2020.

NEWSru.com (2012): Россияне назвали главную проблему в стране: это не дураки и не дороги. http:// www.newsru.com/russia/15oct2012/zkh.html, accessed 13/07/2020.

OECD (2018): Russian Federation - Economic Forecast Summary. http://www.oecd.org/eco/outlook/ economic-forecast-summary-russia-oecd-economic-outlook.pdf, accessed 13/07/2020.

Pew Research Center. (2010): Millennials: A Portrait of Generation Next: Confident, Connected, Open to Change. www.PewResearch.org/Millennials, accessed 13/07/2020.

Rakhlei, M. (2017): Angry Young Russians. www.gmfus.org/blog/2017/07/28/angry-young-russians, accessed 13/07/2020.

Schewe, C. D. - Debevec, K. - Madden, T. J. - Diamond, W. D. - Parment A. -Murphy, A. (2013): 'If you've seen one, you've seen them all!' Are Young Millennials the same Worldwide? Journal of International Consumer Marketing 25(1): 3-15.

Shames, S. L. (2017): Out of the Running: Why Millennials Reject Political Careers and Why it Matters. New York, NY: New York University Press.

Shea, D. (2004): Throwing a Better Party: Local Mobilizing Institutions and the Youth Vote. Circle Working Paper 13.

Stockemer, D. (ed.) (2018): Populism Around the World. A Comparative Perspective. Berlin, Heidelberg: Springer.

Stokes, B. (2015): Europe's Kids are Moody and Depressed. Foreign Policy. http://foreignpolicy.com/2015/ 02/23/europe-millenial-economy-pew-spain-germany/, accessed 13/07/2020.

Transparency International. (2017): Corruption Perceptions Index. https://www.transparency.org/news/ feature/corruption_perceptions_index_2017, accessed 13/07/2020.

Twenge, J. M. (2006): Generation Me: Why Today's Young Americans are more Confident, Assertive, Entitled-And More Miserable than Ever Before. New York: Free Press.

Twenge J. M. - Campbell W. K. (2009): The Narcissism Epidemic: Living in the Age of Entitlement. New York: Free Press.

Twenge, J. M. - Konrath, S. - Foster, J. D. - Campbell, W. K. - Bushman, B. J. (2008): Egos Inflating over Time: A Cross-Temporal Meta-Analysis of the Narcissistic Personality Inventory. Journal of Personality 76(4): 875-902. 
U.S. Census Bureau. (2013): Annual Estimates of the Resident Population by Single Year of Age and Sex for the United States: April 1, 2010 to July 1, 2013. http://factfinder2.census.gov/faces/tableservices/jsf/ pages/productview.xhtml?src5bkmk, accessed 13/07/2020.

Walton, H. Jr. - Smith R. C. (2014): American Politics and the African American Quest for Universal Freedom. Boston: Pearson.

Williams, K. C. - Page, R. A. - Petrosky, A. R. - Hernandez, E. H. (2010): Multi-generational Marketing: Descriptions, Characteristics, Lifestyles and Attitudes. Journal of Applied Business and Economics 11(2): 21-36.

YouGov. (2016): YouGov Exitpoll on the British Referendum June 24 2016. https://d25d2506sfb94s. cloudfront.net/cumulus_uploads/document/oxmidrr5wh/EUFinalCall_Reweighted.pdf, accessed 13/ $07 / 2020$.

Open Access. This is an open-access article distributed under the terms of the Creative Commons Attribution-NonCommercial 4.0 International License (https://creativecommons.org/licenses/by-nc/4.0/), which permits unrestricted use, distribution, and reproduction in any medium for non-commercial purposes, provided the original author and source are credited, a link to the CC License is provided, and changes - if any - are indicated. 